\title{
Variation of the surface chromatic properties of exposed concrete façades treated with anti-graffiti products
}

\author{
Variación de las propiedades cromáticas superficiales de las fachadas de hormigón visto tratadas \\ con productos antigrafiti
}

\author{
Elena Sarabia Castelló (Main and Contact Author) \\ Departamento de Construcción y Tecnología Arquitectónicas, Universidad Politécnica de Madrid, España. \\ Avda. Juan de Herrera, 4. 28040, Madrid (España). \\ +34669956900 \\ esc@esarquitectura.net \\ Alfonso García Santos \\ Departamento de Construcción y Tecnología Arquitectónicas, Universidad Politécnica de Madrid, España. \\ alfonso.garciasantos@upm.es
}

\begin{abstract}
The research analyses the variation of the surface chromatic properties, hue and brightness, sustained by the Portland cement mortar support, due to the application of anti-graffiti protective treatments. The test specimens were digitally analysed using a methodology based on the RGB model, which resulted in the image histogram values of each test specimen treated. The same mortar type without protection was used as the base to quantify the modification. Surface chromatic variation is determined by the type of anti-graffiti treatment used and by the base material on which it is applied. The result is that all the anti-graffiti products studied cause the variation of the supports' hue and brightness, with the mortar made from grey Portland cement type CEM II/B-M(V-L) 32,5 N (Mb) being the one with less variation of its surface chromatic characteristics once treated. In addition, the fluorinated acrylate component (A4) causes the smalles deviation of the absolute hue and brightness values obtained from the samples analysed.
\end{abstract}

Keywords: Mortar, graffiti, polymers, surface properties, colour.

\begin{abstract}
Resumen
La investigación analiza la variación de las propiedades cromáticas superficiales, tonalidad y luminosidad, que sufre el soporte de mortero de cemento portland por la aplicación de tratamientos protectores antigrafiti. Las probetas fueron analizadas por procedimientos digitales mediante una metodología basada en el modelo RGB, obteniendo los valores de histograma de imagen de cada muestra tratada y tomando como base para cuantificar la modificación, el mismo tipo de mortero sin protección. La variación cromática superficial está determinada por el tipo de tratamiento antigrafiti utilizado y por el material base sobre el que se aplica, obteniéndose como resultado que todos los productos antigrafiti estudiados producen variación de tonalidad y luminosidad en los soportes, siendo el mortero elaborado con cemento portland gris de tipo CEM II/B-M(V-L) $32,5 \mathrm{~N}(\mathrm{Mb})$ el que presenta menor variación de sus características cromáticas superficiales una vez tratado. Además, el antigrafiti de componente acrilato con copolímeros de flúor (A4) produce la menor desviación de los valores absolutos de tonalidad y luminosidad obtenidos en las muestras analizadas.
\end{abstract}

Palabras Claves: mortero, grafiti, polímeros, propiedades superficiales, color.

The research analyses the variation of the chromatic properties of mortars treated in surface with anti-graffiti products commercialised as colourless, establishing which treatment causes the lesser alteration to its hue and brightness. Once the selection of the minimum number of mortar types has been defined in relation to their usage frequency during the construction of exposed concrete façades, the base surface chromatic characteristics for each type selected are established, and the protective treatment causing the lesser modification is obtained. Samples of four mortar types are used, made with four different types of Portland cement: three grey cements ( $\mathrm{Ma}, \mathrm{Mb}$ and $\mathrm{Mc}$ ) and a white cement (Md).

Depending on the duration of the protection on the support on which it is applied, anti-graffiti treatments are organised in three main groups: expendable, semi-permanent and permanent (Carmona, 2010). Table 1 collects the main characteristics of each group, their advantages and issues (adapted from "Anti-Graffiti-Schutz", w.d.). For this study, the products selected are from the permanent group, where the removal of the graffitis is usally done with solvents, high pressure equipment or methods generally less destructive with the base substrate than those of the other groups. Although more costly, the initial investment is compensated by the durability of each application, since permanent anti-graffiti products remain effective after several cleaning operations. 
This group includes, among others, those with acrylic-siloxane copolymers, polyurethanes, PVF (polyvinyl fluorides), silicones, etc. in their composition (Segalini, De Chirico, De Pinto, \& Pegoraro, 2000).

Table 1. Anti-graffiti products classification. Source: Self-elaboration, 2014.

ADVANTAGE

DISADVANTAGE

\begin{tabular}{|c|c|c|}
\hline \multirow{7}{*}{ EXPENDABLE } & Reversible treatment & The treatments present restrictions of durability \\
\hline & Less expensive than permanent treatments & Products require a continuous maintenance \\
\hline & Simple application & \\
\hline & Colourless coating & \\
\hline & Easy removal (some products with hot water) & \\
\hline & $\begin{array}{l}\text { Average duration of two years, depending on the } \\
\text { treatment and the base substrate on which is applied }\end{array}$ & \\
\hline & Highly permeable to water vapor & \\
\hline \multirow{5}{*}{ SEMI-PERMANENT } & $\begin{array}{l}\text { Single layer products are less expensive than permanent } \\
\text { treatments }\end{array}$ & The treatments present restrictions of durability \\
\hline & $\begin{array}{l}\text { Two layers products have a sacrificable layer which is } \\
\text { removed with hot water }\end{array}$ & Products require maintenance \\
\hline & Paints penetration between the two layers is more difficult & \\
\hline & Colourless coating & \\
\hline & Some products are water vapor permeable & \\
\hline \multirow{5}{*}{ PERMANENT } & Firmly adhere to many substrates & Irreversible treatments, difficult to eliminate \\
\hline & The paintings are easily removed, hardly penetrate graffiti & $\begin{array}{l}\text { Some products are not water vapor permeable } \\
\text { (example: PU component treatments) }\end{array}$ \\
\hline & The treatments do not produce corrosion & $\begin{array}{l}\text { Treatments are sensitive to moisture of the base } \\
\text { substrate }\end{array}$ \\
\hline & Colourless and pigmented coatings & Some treatments become yellow over time \\
\hline & $\begin{array}{l}\text { Some products are water vapor permeable (example: } \\
\text { siloxane component treatments) }\end{array}$ & \\
\hline
\end{tabular}

Problem Description

The way the anti-graffiti products selected for this study spread on the mortar's porous surface, in addition to the adhesion force between both materials, establish the modification of the support's surface properties, causing changes in their chromatic characteristics that are noticeble to the human eye (Horie, 1986). Although these treatments are commercialised as colourless, the aforementioned adhesion to the mortar's surface affects the refraction of the light incident on said mortar, causing the modification of its original colouring.

The adhesion force between both materials is due to several factors but, principally, to the difference of surface tensions existing between the anti-graffiti protection and the base substrate. Their union is guaranteed by the structure of the protective treatment, based on the usage of polymeric elements, which have a lower surface tension than the rest of building materials used habitually.

The application of the anti-graffiti product equalises the mortar's surface tension to that of the paintings or graffitis, reducing greatly their suction but without altering, in general and significantly, the base substrate's permeability to gases and water vapour (Coronado, García, 2014). Thus, no strong bonds (ionic, covalent or metallic) appear between the graffiti and the protected support, only weak bonds (van der Waals forces and Hydrogen bonds), which are easier to remove. In addition to the surface tension, roughness is another factor affecting substantially the anti-adhesive properties between materials (García, 2001).

A wide variety of polymer types is used in the composition of the anti-graffiti products currently commecialised. Each one of them will have a specific surface tension that will interact differently with the mortars on which it is applied, with particular adhesion phenomena, with different degradations and ageing phenomena, causing specific dirtying and, in short, establishing different variations in the perception of the surface chromatic properties for each type of support on which they are used. The aim of the present research is to study and analyse the effect caused on the selected base mortars, depending on their composition, by the different permanent anti-graffiti treatments applied. 
The research works published previously that establish the state of the art regarding the subject analyse the surface chromatic modifications caused by the application of certain protective treatments on different base substrates, using digital procedures for their analysis.

The development of a new testing methodology (Beltramone, García C., \& García S., 2003) enabled the study of the effect that using different form removal products and incorporating plastic superfluidifying additives to the mixture, have on the surface properties of the grey Portland cement mortars used habitually in the construction of exposed concrete; this established that paraffinic form removal products modifies to a lesser extent the colour and texture of the test specimens studied when compared with the base test specimen. A migration of the additives' polymeric particles towards the surface of the samples analysed was noticed, with records of darker hue variations in all the cases and a general reduction of roughness in relation to the base test specimen or test specimens without their incorporation.

The research developed in the Department of Construction and Technology in Architecture of the Superior Technical School of Architecture, Technical University of Madrid, about colour variation of the ceramic support due to the application of anti-graffiti products (García, Conci, 2005), concluded that the chromatic modification sustained by the support is caused by the type of treatment applied but mainly by the type of base material, in that case rustic cermic, quite more sensitive to have its chromatic properties, brightness and hue modified than industrial ceramic. The digital colour measurement was done with image histograms values, using the RGB colour space and adapting the methodology of the previous research work to a model that offers device independence, since the results do not depend on monitors (HSB model) or inks (CMYK model).

The Spanish standard regulating the measurement of surface colour is UNE-EN 15886 (AENOR-CEN, 2011); it is based on the CIE $\mathrm{L}^{*} \mathrm{a}{ }^{*} \mathrm{~b}^{*}$ colour space, which obtains absolute colour values. This article proposes the usage of the methodology based on the digital colour measurement with the RGB model, in which each colour appears split according to its three primary spectrum components (red, green and blue) and is also characterised by the value of its brightness. Said model enables the measurement of the relative hue and brightness values, establishing the chromatic variation generated, noticeable to the human eye, in the sample analysed in relation to a base test specimen, which allows quantifying the effect caused by each treatment type.

The implementation of this testing methodology (Coronado, 2012) concluded with the obtaining of a mathematical model that can predict the final colour of the ceramic treated with water-repellent products taking as a base the initial colour of non-treated ceramic. Its usage has also allowed the quantification of the effect that applying different varnishes, commercialised as colourless, causes on a certain type of timber (Rodríguez, 2012), by analysing the treatment that causes a lesser variation of its surface chromatic properties: hue and brightness.

In addition, the inverse gas chromatography results of the tests performed in the "Eduardo Torroja" Institute for Construction Science (CSIC, Spanish National Research Council) of Madrid (Carmona, Martínez, Sobrados \& Blanco, 2010) note that, out of the anti-graffiti products studied -a new compound synthesised in the Ceramic and Glass Institute of the CSIC, Zr-Ormosil, and a commercial product of fluorinated nature, Protectosil Antigraffiti from Degussa-, on the surface of five building materials -cement mortar, lime mortar, limestone, granite and brick-, in terms of compatibility, interaction, effectiveness and durability, the second one is more efficient, reducing the surface energy of lime mortar, limestone and granite.

The conclusions reached in the study explain the higher effectiveness of the graffiti cleaning systems in materials coated with this product, clearly influenced by the porosity, the cohesion and, particularly, the roughness of the suports.

Materials

\section{Cement mortars}

The selection of the cements for the preparation of the mortar samples is done according to their usage frequency in the construction of exposed concrete façades. Test specimens made from four types of Portland cement, three grey cements (CEM II/B-L 32,5 N, CEM II/B-M(V-L) 32,5 N and CEM II/A-V 42,5 R), referred to in the research as Ma, Mb and Mc respectively, and a white cement (BL II/A-L 42,5 R), referred to as Md. The prismatic test specimens were prepared as specified in Standard UNE-EN 196-1, "Methods of testing cement", Part 1 (Determination of mechanical strength) (AENOR-CEN, 2005).

\section{Anti-graffiti products}

Out of the wide range of commercialised permanent anti-graffiti products, the selection for this research has been done according to their composition, with the aim of observing the variation that each one of them causes on the different types of mortar on which they are applied. Table 2 collects the main characteristics of the five chosen products. 
Table 2. Selection and characteristics of the anti-grafiti products. Source: Self-elaboration, 2014.

ANTI-

\begin{tabular}{|c|c|c|c|c|c|c|}
\hline $\begin{array}{l}\text { GRAFFITI } \\
\text { № }\end{array}$ & COMPONENTS & & SOLUTION & DENSITY & FINISH & PRODUCT \\
\hline A1 & Polyurethane resin & \multirow{3}{*}{$\begin{array}{l}\mathrm{Bi}- \\
\text { component }\end{array}$} & Aqueous & $1,08 \mathrm{gr} / \mathrm{cm}^{3}$ & Colourless & $\begin{array}{l}\text { EG A-G COATING WB } \\
\text { ULTRAMATT CLEAR }\end{array}$ \\
\hline A2 & Polyurethane acrylate & & Aqueous & $1,08 \mathrm{gr} / \mathrm{cm}^{3}$ & Colourless & ENCEPHOB NANOPERM T \\
\hline A3 & $\begin{array}{l}\text { Aliphatic acrylic } \\
\text { polyurethane silicone }\end{array}$ & & Aqueous & $0,99 \mathrm{gr} / \mathrm{cm}^{3}$ & Colourless & ANTIGRAFFITI MAPER \\
\hline A4 & Fluorinated acrylate & \multirow{2}{*}{$\begin{array}{l}\text { Mono- } \\
\text { component }\end{array}$} & Aqueous & $1,01 \mathrm{gr} / \mathrm{cm}^{3}$ & Colourless & MACS FLUOROSIL CLASSIC \\
\hline A5 & $\begin{array}{l}\text { Organofunctional silane } \\
\text { with fluoride dispersions }\end{array}$ & & Aqueous & $1,06 \mathrm{gr} / \mathrm{cm}^{3}$ & Colourless & $\begin{array}{l}\text { FK-GRAFFI PROTECT } \\
\text { EXTREME }\end{array}$ \\
\hline
\end{tabular}

Depending on the way the chosen products are spread on the surface of the mortars on which they are applied, we can classify the selection in three treatment groups. Firstly, primers (the products referred to as A1 and 2 in the research belong to this group), great polymeric molecules that coat the mortar with a pore-free film of a specific thickness that prevents the entry of water and the diffusion of vapour. Secondly, impregnations (the treatment referred to as A3 belongs to this group), that penetrate the pores and adhere to their walls without obstructing them, allowing permeability to water vapour and other gases.

Lastly, fluorinated polymers (the products referred to as A4 and A5), with interesting properties such as their chemical and thermal stability, their water-repellent and dirt-repellent properties (a consequence of the low surface energies of the fluorinated groups), permeability to air and water vapour, properties that have been used not only for the development of anti-graffiti formulations, but also water-repellent and consolidating products, used for the conservation and restoration of historical buildings (Chávez, Álvarez, 2005).

\section{Colourimetric test}

The methodology used in the colourimetric test is based on studies published previously, in which the digital colour measurement is done by using the Photoshop software as an observation and analysis tool. From prior research works carried out on cement mortars, ceramic pieces and timbers, an analytical procedure is designed specifically for Portland cement mortars treated with antigraffiti products.

Five test specimens of each type of mortar prepared are used. For each sample, half of one of its faces is treated with a different anti-graffiti product by brush and until the support is saturated, following the manufacturer's recommendations. The drying time recommended by the manufacturers for the products to be completely dry to the touch ranges from $1 \mathrm{~h}$ to $4 \mathrm{~h}$. Both the application of the products and the drying of the test specimens are done in laboratory environmental conditions.

The data recording of the samples is done seven days after the application of the treatment, matching up the products' setting time, specified in their data sheets, with the concretes' setting time, during which they develop close to $80 \%$ of their strength. Photographs are taken with a Canon IXUS 90 IS, 10,0 megapixels digital camera, placed on a reproduction table. The mortar specimens are placed in the base of the table, so that the upper face of the sample is separated $40 \mathrm{~cm}$ from the camera's lens. The reproduction table is lit with four $75 \mathrm{~W}$ lamps, reaching at their base an illuminance value of 760 lux (measured with a Koban digital luxmeter, model KI-6610) (Figure 1).

With the help of a remote control, six pictures of each test specimen placed on the reproduction table are taken, in which the whole sample presented is observed. These pictures are referred to as original images and with the Photoshop CS6 software two sections of each one of them are cut, as shown in Figure 2: the central part of the area of the non-treated test specimen's face and the central part of the area of the treated test specimen's face, the latter being the images analysed (Coronado, García, 2011). 


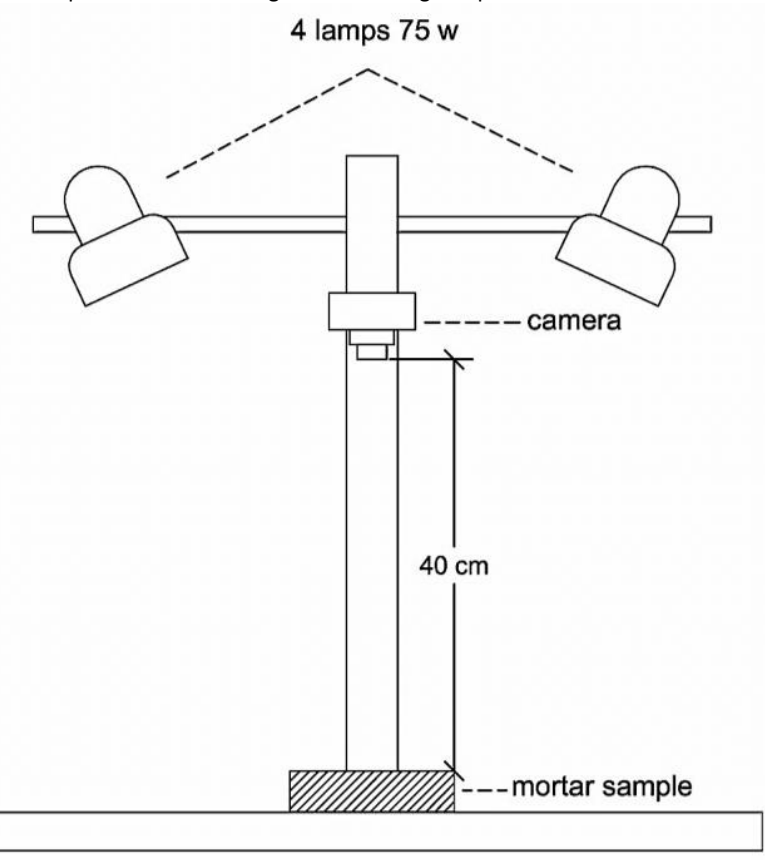

Figure 2. Diagram of data gathering. Source: Self-elaboration, 2014.
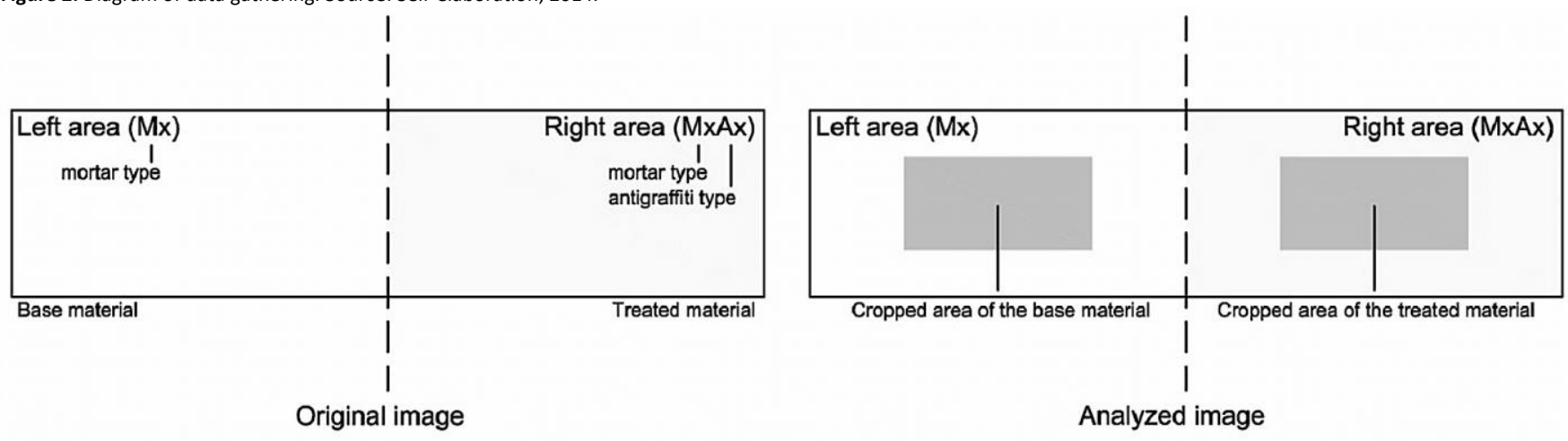

For the tests regarding this research, the digital colour measurement was established by using the RGB colour space, which uses as primary colours red, green and blue. Any colour obtained in the pictures studied is split according to its three primary spectrum components (red, green and blue) and is also characterised by its brightness value. In order to visualise the hue distribution of each image, their histograms are checked. An image historgram consists in a bar graph with 256 columns where the horizontal axis represents the different hues from pure black (value 0 , to the left) to pure white (value 255, to the right) and the vertical axis represents the number of pixels that the image contains for each of the hues represented in the horizontal axis.

The data obtained with the histogram for each image analysed is recorded in data sheets that collect the quantifiable values of each sample, both of the area of the base test specimen, without treatment, and of the area of the test specimen treated with each type of anti-graffiti product applied, as shown in the following Table 3. 
Table 3. Areas of the base and treated sample with their histogram values. Source: Self-elaboration, 2014.

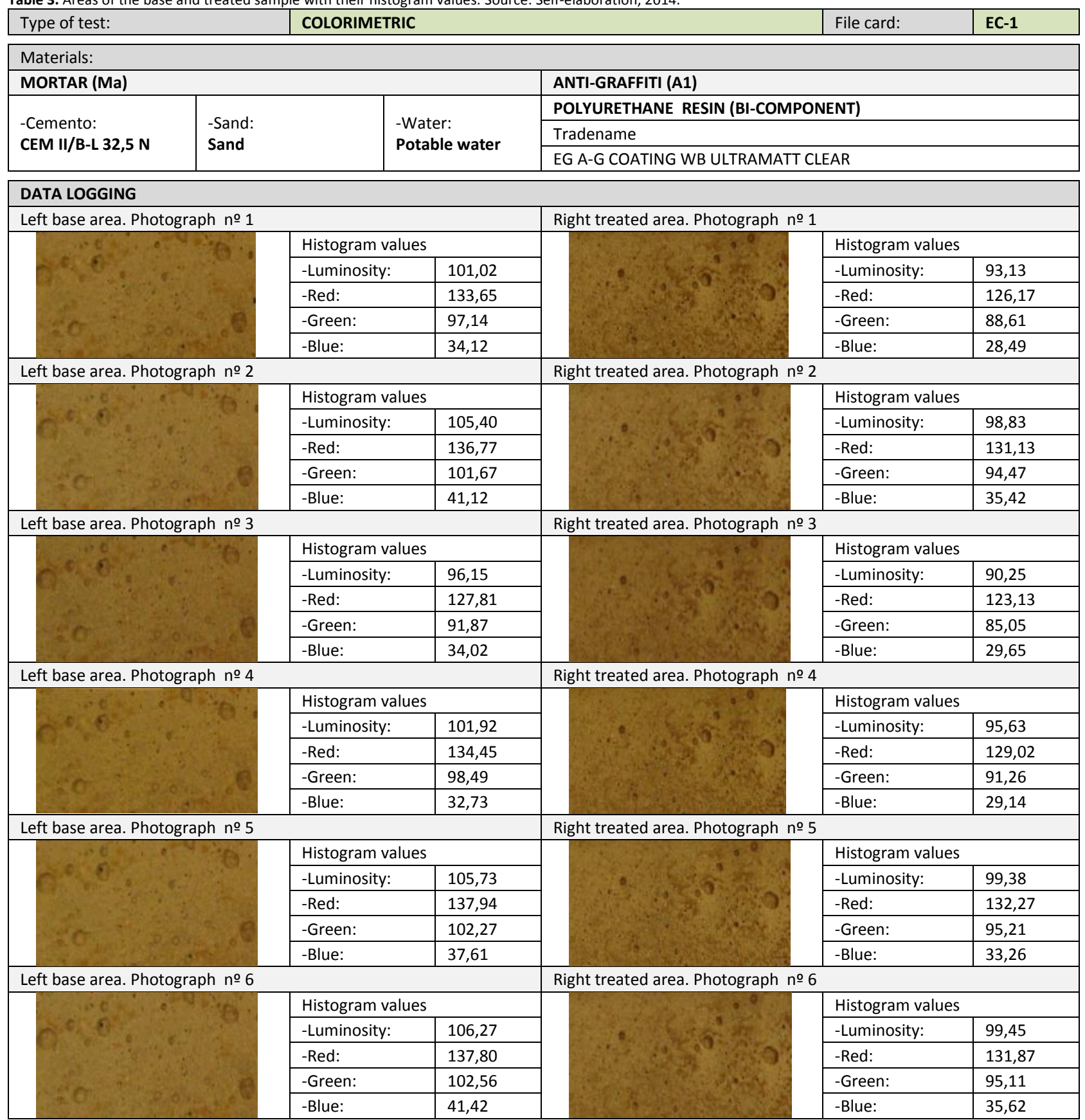


The following images, Figures 3, 4, 5 and 6, represent graphically the histogram values obtained from the pictures analysed of the test specimens of each of the selected mortar types. For each one of them, the data obtained from the measurement of the values of the area of the face with no treatment (base) and of the area of the face treated with each type of anti-graffiti product.

Figure 3. Luminosity: comparative between values of base material and treated material área. Source: Self-elaboration, 2014.

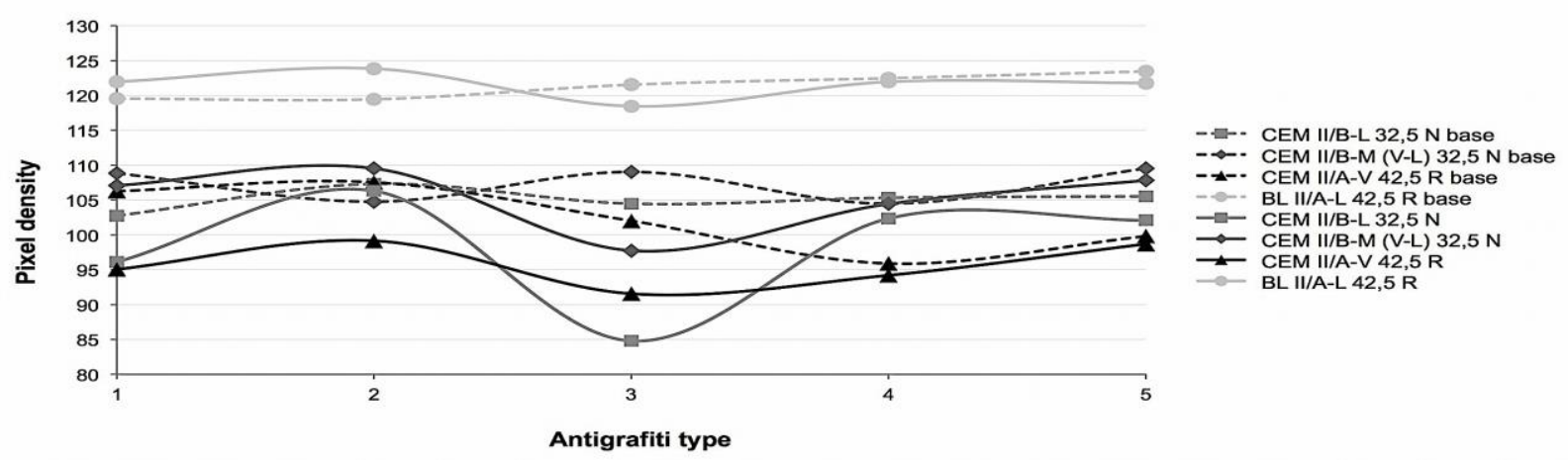

Figure 4. Red: comparative between values of base material and treated material área. Source: Self-elaboration, 2014.

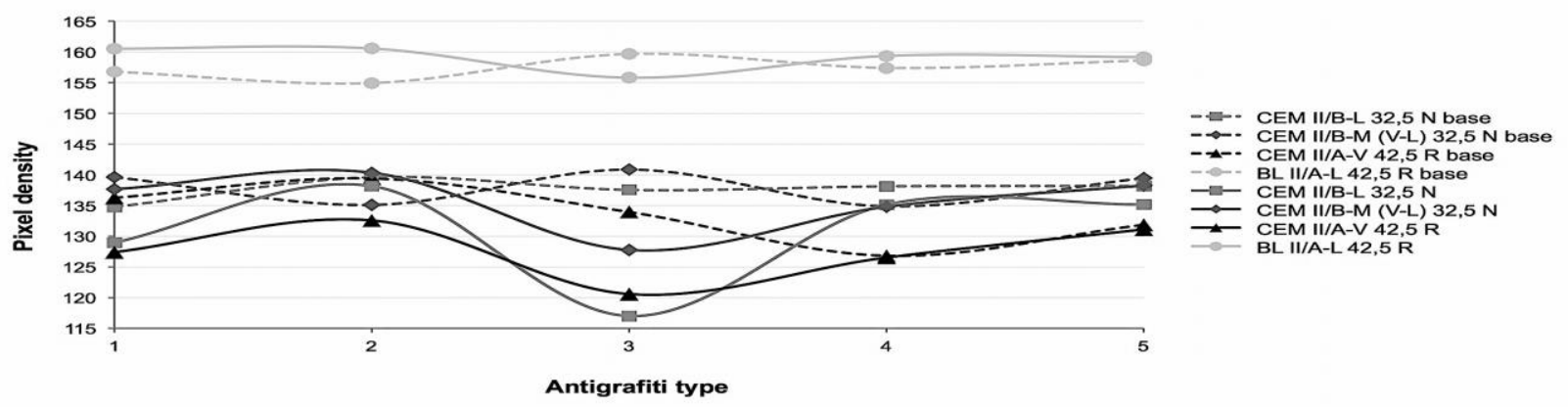

Table 4 offers a clearer reading of the results since the data from the previous figures, regarding the brightness and hue values of the areas of the test specimens with treatment, are established in relative percentage in relation to the initial values of the areas of the test speciments without treatment. For each mortar type and with a grey background, the anti-graffiti product presenting the lesser variation of each histogram value (brightness, red, green and blue) is highlighted.

Table 4. Chromatic decomposition and brightness values in percent deviation in relation to the initial values of the mortar without treatment.

\begin{tabular}{|c|c|c|c|c|c|}
\hline & LUMINOSITY & RED & GREEN & BLUE & \\
\hline \multirow{5}{*}{$\begin{array}{l}\text { Ma } \\
(\text { CEM II/B-L 32,5 N) }\end{array}$} & $(-) 6,46$ & (-) 4,31 & (-) 7,45 & (-) 13,33 & A1 \\
\hline & (-) 0,95 & (-) 1,00 & $(-) 1,06$ & $(+) 1,81$ & A2 \\
\hline & $(-) 18,85$ & (-) 14,92 & (-) 18,85 & $(-) 24,02$ & A3 \\
\hline & $(-) 2,83$ & $(-) 2,17$ & $(-) 2,83$ & $(-) 6,34$ & A4 \\
\hline & $(-)$ 3,27 & (-) 2,19 & $(-) 3,27$ & $(-) 8,81$ & A5 \\
\hline \multirow{5}{*}{$\begin{array}{l}\text { Mb } \\
(\text { CEM II/B-M (V-L) 32,5 N) }\end{array}$} & $(-) 1,62$ & $(-) 1,40$ & $(-) 1,76$ & $(-) 1,60$ & A1 \\
\hline & (+) 4,55 & (+) 3,88 & (+) 4,66 & (+) 8,99 & A2 \\
\hline & (-) 10,35 & $(-) 9,28$ & (-) 10,70 & (-) 15,07 & A3 \\
\hline & $(-) 0,05$ & (-) 0,06 & $(-) 0,01$ & $(-) 0,58$ & A4 \\
\hline & $(-) 1,57$ & $(-) 0,86$ & $(-) 1,72$ & $(-) 5,40$ & A5 \\
\hline \multirow{5}{*}{$\begin{array}{l}\text { Mc } \\
\text { (CEM II/A-V 42,5 R) }\end{array}$} & (-) 10,53 & $(-) 6,50$ & (-) 12,27 & (-) 23,01 & A1 \\
\hline & $(-) 7,80$ & $(-) 4,89$ & $(-)$ 9,34 & (-) 14,07 & A2 \\
\hline & (-) 10,25 & $(-)$ 9,97 & $(-) 9,63$ & (-) 21,81 & A3 \\
\hline & $(-) 1,76$ & $(-) 0,24$ & $(-) 2,30$ & $(-) 9,06$ & A4 \\
\hline & (-) 1,12 & (-) 0,57 & (-) 1,47 & (-) 1,57 & A5 \\
\hline \multirow{5}{*}{$\begin{array}{l}\text { Md } \\
\text { (BL II/A-L 42,5 R) }\end{array}$} & (+) 1,98 & (+) 2,38 & $(+) 1,54$ & (+) 3,98 & A1 \\
\hline & (+) 3,67 & $(+) 3,63$ & $(+) 3,46$ & $(+) 7,27$ & A2 \\
\hline & $(-) 2,53$ & $(-) 2,42$ & $(-) 1,97$ & (-) 10,96 & A3 \\
\hline & $(-) 0,42$ & $(+) 1,24$ & $(-) 1,00$ & $(-) 6,15$ & A4 \\
\hline & $(-) 1,36$ & (+) 0,33 & $(-) 1,89$ & $(-) 8,16$ & A5 \\
\hline
\end{tabular}


The sign - beside each value establishes that the absolute value obtained in the measurement of the area with treatment is below the absolute value of the measurement of the area of the base test specimen or test specimen without treatment. The sign + beside each value establishes that the absolute value obtained in the measurement of the area with treatment is over the absolute value of the measurement of the area of the base test specimen or test specimen without treatment.

Figure 5. Green: comparative between values of base material and treated material área. Source: Self-elaboration, 2014.

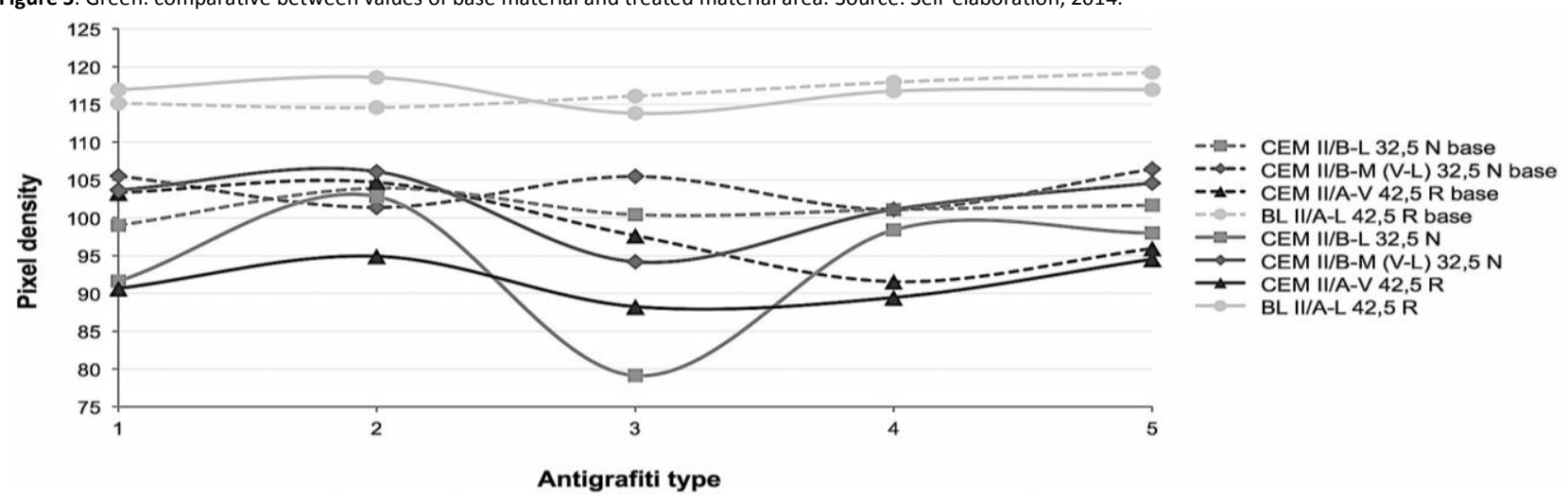

Figure 6. Blue: comparative between values of base material and treated material área. Source: Self-elaboration, 2014.

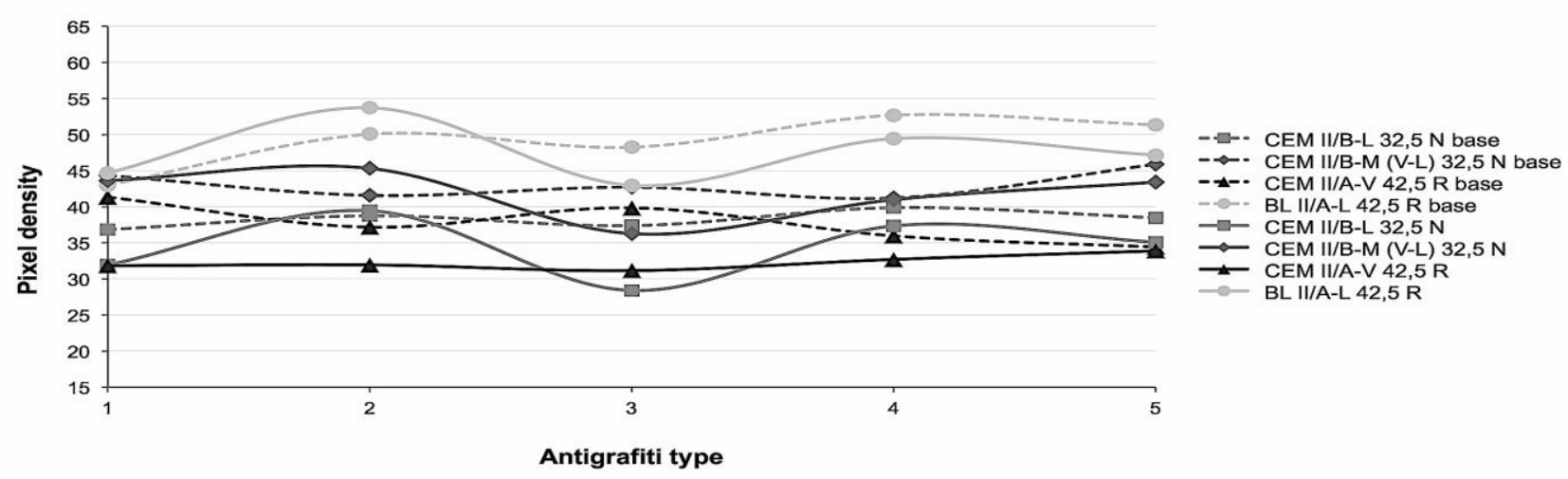

Discussion

All the anti-graffiti treatments cause, to a greater or a lesser extent, a variation in hue and brightness of the samples, although differences between them can be established depending on the type of mortar used when preparing the test specimens. In general, the mortars prepared with the three types of grey Portland cement ( $M a, M b$ and $M c)$ tend to have the same behaviour, a reduction (negative sign) of the absolute values in each hue and brightness with the application of most of the anti-graffiti products, regardless of their composition. However, the mortars prepared with the white Portland cement (Md) tend to have a different behaviour to the previous ones (increase of the absolute values) mainly with the application of the anti-graffiti products referred to as $\mathrm{A} 1$ and $\mathrm{A} 2$, primers with polyurethane component.

In relation to the production process, the chromatic classification of the base material in the white Portland cement mortar (value range $\mathrm{R}$ 160-150, G $120-115$, B 55-40) has been noted to be different to the three grey Portland cement mortars, which are included in the same chromatic classification (value range R 145-125, G 110-90, B 45-30). This chromatic property of thebase substrate affects the obtaining of similar results when applying the protective treatments in the grey Portland cement mortars (Ma, $\mathrm{Mb}$ and $\mathrm{Mc}$ ) and a different result in the white Portland cement mortar (Md).

The general analysis of the colour split into RGB (red-green-blue) in the four mortar types points that out of the three colour spaces, the blue one varies with a greater absolute value in all of them, whereas the red one presents the lesser modification. The green colour shows a variable behaviour between the calues of the red colour and the blue colour. It is therefore possible to say that the colour perception in mortars treated with anti-graffiti products modifies their hue, tending towards hues referred to as "warm" due to the presence of the colour red and a loss of the colours blue and green.

Brightness follows a similar behaviour to that of the colour spaces, varying in general with negative sign (reduction of the value) in all four analysed mortar types and with the application of most of the treatments, regardless of their composition. 
The application of protective anti-graffiti treatmens, commercialised as colourless, on exposed concrete surface causes, to a greater or a lesser extent, variations of its surface chromatic properties. These modifications are established by the composition of the anti-graffiti product used but, principally, by the material on which they are applied.

\section{Choice of base material}

The results of the research in relation to the base material suggest that for the construction of exposed concrete façades in which the application of protective anti-graffiti treatments is expected, the selection of grey Portland cements type CEM II/B-M(V-L) 32,5 $\mathrm{N}(\mathrm{Mb})$ is recommended during the concrete's production process, since the variations in hue and brightness in the mortars prepared with this type of cement are, in general, of lower absolute values than the other three types analysed.

In the event that the designer intends the construction of exposed concrete façades in a white colour, it's worth mentioning that the tests made with the impregnation of aliphatic acrylic polyurethane component (A3) generate very different results in its application on mortar prepared with the white Portland cement selected, BL II/A-L 42,5 R (Md). While the results in the first three mortars are similar (with greater chromatic modifications than those obtained by applying on them the rest of anti-graffiti treatments), in the last one the variations observed in absolute values are within four and five times smaller when compared to the previous ones, but very similar to those obtained in all the samples of this type of mortar, with cement BL II/A-L 42,5 R (Md), with the application of the other protective treatments.

\section{Choice of anti-graffiti product}

Taking into account the results obtaines in the research and regarding exposed concrete façades already built, in which the type of cement used for the preparation of the concrete is established, the choice of anti-graffiti treatment should be made based on its composition, selecting in each case the protection that causes the lesser variation of absolute value of the three hue components (red, green and blue) and of the brightness.

Products of polyurethane acrylate component (A2) are suggested for exposed concrete façades made with grey Portland cement type CEM II/B-L 32,5 N (Ma), because it's the concrete in which this type of treatment causes the lesser modification in the colouring and brightness of its four components. Anti-graffiti products of aliphatic acrylic polyurethane silicone component (A3) are recommended for exposed concrete façades made with white Portland cement type BL II/A-L 42,5 R (Md). The application of protective products of organofunctional silane with fluoride dispersions component (A5) obtain the best results when used in concretes made with grey Portland cement type CEM II/A-V 42,5 R (Mc), causing in them a lesser modification of the absolute value in two out of the three colour spaces, green and blue, and in the brightness, when compared with concretes prepared with the other types of cement studied.

Lastly, the anti-graffiti products of polyurethane resin component (A1) and those of fluorinated acrylate component (A4) obtain the best results when applied on concretes made with grey Portland cement type CEM II/B-M(V-L) 32,5 N (Mb). However, by comparison, the modification of the hue and brightness absolutes values is lesser when using the latter (A4), virtually imperceptible. It was also the sample with the lesser deviaton of all the hue and brightness absolute values obtained from the mortar test specimens analysed. 
Assoziation Gütegemeinschaft Anti-Graffiti E.V. (2011). Anti-Graffiti-Schutz.

Beltramone, A., García Cruz, F. A., \& García Santos, A. (2003). Modificaciones de las propiedades superficiales en el hormigón visto, por la utilización de diferentes tipos de desencofrantes y aditivos plásticos. Materiales de Construcción, 53(270), 71-78. http://dx.doi.org/10.3989/mc.2003.v53.i270.280

Carmona Quiroga, P. M. (2010). Estudio del comportamiento de dos tratamientos antigraffiti como protectores de materiales de construcción: interacción antigraffiti-substrato, propiedades y durabilidad. Complutense University of Madrid.

Carmona Quiroga, P. M., Martinez Ramirez, S., Sobrados, I., \& Blanco Varela, M. T. (2010). Interaction between two anti-graffiti treatments and cement mortar (paste). Cement and Concrete Research, 723-730. http://dx.doi.org/10.1016/j.cemconres.2010.01.002

Chávez, J. A., \& Álvarez, O. (2005). Metodología para el diagnóstico y restauración de edificaciones. Revista de La Construcción, 4(2), 47-54.

Coronado Martín, J. A. (2012). Influencia de los productos hidrofugantes en las propiedades superficiales de las cerámicas porosas utilizadas en cerramientos exteriores cara vista. Polytechnic University of Madrid.

Coronado Martín, J. A., \& García Santos, A. (2011). La influencia de los productos hidrofugantes en las modificaciones cromáticas del ladrillo cerámico. Materiales de Construcción, 61(304), 597-611. http://dx.doi.org/10.3989/mc.2011.57810

Coronado Martín, J. A., \& García Santos, A. (2014). Application method of water repellent products and its influence on the suction process on the facade of ceramic brick. Revista de La Construcción, 13(3), 3-9. http://dx.doi.org/10.4067/S0718-915X2014000300001

García Santos, A. (2001). Los plásticos en la construcción II (Primera). Madrid: Cuadernos del Instituto Juan Herrera, Escuela Técnica Superior de Arquitectura.

García Santos, A., \& Conci Rinaudo, M. (2005). Variación del color del soporte cerámico tratado con pintura antigraffiti. Materiales de Construcción, 55(278), 55-68. http://dx.doi.org/10.3989/mc.2005.v55.i278.189

Horie, V. (1986). Materials for Conservation: Organic consolidants, adhesives and coatings. Oxford: Butterworth-Heinemann.

Rodríguez Rodríguez, A. (2012). Influencias de los barnices incoloros en las propiedades superficiales de las maderas de construcción. Polytechnic University of Madrid.

Segalini, S., De Chirico, A., De Pinto, G., \& Pegoraro, M. (2000). Antigraffiti removers and antigraffiti coatings. In XXV FATIPEC Congress (pp. 323337). Turín: FATIPEC

UNE-EN 15886. (2011). Conservación del patrimonio cultural. Métodos de ensayo. Medición del color de superficies. Madrid, España: Asociación Española de Normalización y Certificación (AENOR).

UNE-EN 196-1. (2005). Métodos de ensayo de cementos. Parte 1: Determinación de resistencias mecánicas. Madrid, España: Asociación Española de Normalización y Certificación (AENOR) 